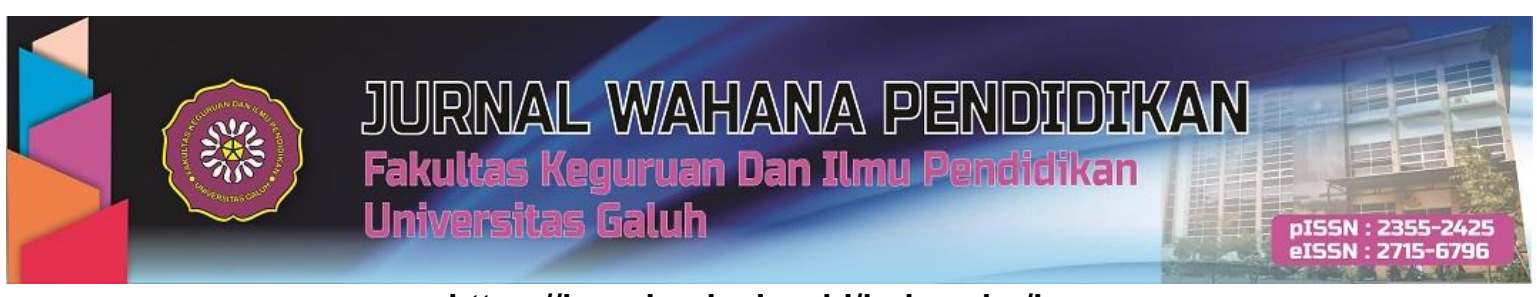

https://jurnal.unigal.ac.id/index.php/jwp

\title{
MENINGKATKAN HASIL BELAJAR MATEMATIKA SISWA PADA MATERI BANGUN RUANG MELALUI PEMANFAATAN ALAT PERAGA
}

\author{
Tatang 1 \\ ${ }^{1}$ SD Negeri Tamansari, Kecamatan Kawalu, Kota Tasikmalaya, Jawa Barat, Indonesia \\ Email: otang131161@gmail.com
}

\begin{abstract}
One of the efforts to increase students' motivation, activeness, and interest in mathematics is by using teaching aids during on-going learning. The use of teaching aids can improve the quality of learning and help students understand the concept of the material being studied which will have an impact on increasing student learning outcomes. This study ha a purpose was to describe the increase in mathematics learning outcomes of grade VI SD Negeri Tamansari Kota Tasikmalaya on geometry through the use of teaching aids. This research is a classroom action research conducted on 19 grade students. The research was conducted in two cycles. Each cycle consists of stages of planning, action, observation, and reflection. The instruments used were tests and student observation sheets. Based on the results of the study, it was obtained that the average value of mathematics increased in the first cycle of students who met the Minimum Completion Criteria (KKM) as many as 5 students or $25 \%$ while the other $75 \%$ were not yet complete so the study continued to cycle II. In the second cycle student learning outcomes experienced a significant increase, namely $100 \%$ of students had achieved completeness. The average score of students also increased in the first cycle of 58.5 , while the average score in the second cycle was 80 . These results have met the established success criteria so that it can be said that the use of teaching aids in learning materials for geometry can improve the results. student learning.
\end{abstract}

Keywords: Learning Outcomes, Geometry, Teaching Aids

\begin{abstract}
ABSTRAK
Salah satu upaya guna meningkatan motivasi, keaktifan, dan minat siswa pada matematika yakni dengan menggunakan alat peraga pada saat pembelajaran belangsung. Penggunaan alat peraga mampu meningkatkan kualitas pembelajaran dan membantu siswa dalam memahami konsep materi yang dipelajari yang akan berdampak pada meningkatnya hasil belajar siswa. Penelitian dilaksanakann bertujuan guna memberikan deskripsi peningkatan hasil belajar matematika siswa kelas VI SD Negeri Tamansari Kota Tasikmalaya pada materi bangun ruang dengan memanfaatkan alat peraga. Penelitian termasuk tindakan kelas dimana pelaksanaannya pada siswa kelas VI yang jumlahnya 19 orang. Pelaksanaan penelitian dilakukan dua siklus. Masing-masing siklus terdiri dari tahapan perencanaan (planning), tindakan (action), pengamatan (observation), dan refeleksi (reflection). Instrumen yang digunakan adalah tes dan lembar observasi siswa. Berdasarkan hasil penelitian diperoleh data nilai rata-rata matematika mengalami peningkatan pada siklus I siswa yang memenuhi Kriteria Ketuntasan Minimum (KKM) adalah sebanyak 5 orang siswa atau sebesar $25 \%$ sedangkan $75 \%$ lainnya belum tuntas sehingga penelitian dilanjutkan ke siklus II. Pada siklus II hasil belajar siswa mengalami peningkatan yang signifikan yaitu $100 \%$ siswa sudah mencapai ketuntasan. Rata-rata nilai siswa juga mengalami peningkatan pada siklus I sebesar 58,5 sedangkan perolehan nilai rata-rata pada siklus II sebesar 80 . Hasil tersebut sudah memenuhi kriteria keberhasilan yang ditetapkan sehingga dapat dikatakan bahwa penggunaan alat peraga pada pembelajaran materi bangun ruang dapat meningkatkan hasil belajar siswa.
\end{abstract}

Kata Kunci: Hasil Belajar, Materi Bangun Ruang, Alat Peraga

Cara sitasi:

Tatang. (2020) Meningkatkan Hasil Belajar Matematika Siswa pada Materi Bangun Ruang melalui Pemanfaatan Alat Peraga. Jurnal Wahana Pendidikan, 8(1), 77- 84.

Sejarah Artikel:

Dikirim Desember 2020, Direvisi Januari 2021, Diterima Januari 2021. 


\section{PENDAHULUAN}

Matematika menjadi ilmu dasar dengan perkembangan yang sangat pesat secara kegunaan maupun teorinya. Matematika yang dipelajari merupakan perkembangan masa lalu, masa saat ini, dan mungkin masa mendatang yang harus diperhatikan perkembangannya. Disamping itu matematikapun memberikan perhatian pada manfaatnya, misalnya yakni pembentukan pribadi luhur dan meningkatkan pertumbuhan perkembangan kemampuan berpikir serta dalam penerapan dan penguasaan matematika itu sendiri (Suwardi et.al, 2014).

Sayangnya matematika sering dianggap pelajaran yang sulit oleh siswa sehingga berdampak pada menurunnya motivasi dan hasil belajar siswa. Paradigma tersebut telah berlangsung sejak lama dan bahkan mungkin akan terus berlanjut kedepannya jika tidak ada upaya untuk merubahnya.

Salah satu upaya guna meningkatkan motivasi, keaktifan, dan minat siswa pada matematika yakni pelaksanaan pembelajaran yang menarik. Keaktifan dalam pembelajaran membutuhkan strategi, model, metode, dan media yang disesuaikan dengan materi pembelajaran. Tak dapat dipungkiri bahwa hal yang diharapkan oleh guru dan siswa adalah pembelajaran matematika yang dapat meningkatkan motivasi belajar serta mampu meningkatkan pemahaman matermatika dikarenakan akan berdampak pada meningkatnya hasil belajar siswa.

Penggunaan alat peraga sebagai media pembelajaran mampu meningkatkan kualitas pembelajaran, memudahkan dalam memahami materi, menarik dan efektif untuk membuat pembelajaran menjadi bermakna. Motivasi dan pemahaman siswa akan meningkat dengan penggunaan alat peraga karena siswa belajar melalui benda-benda kongkrit sebagai visualisasi untuk memahami konsep yang abstrak. Pada matematika, penyajian konsep abstrak berbentuk kongkrit akan lebih mudah dimengerti dan dipahami (Komalasari,2010).

Penggunaan alat peraga dapat mendukung terhadap tercapainya tujuan pembelajaran matematika yang disampaikan oleh Depdiknas (2003), yakni 1) mengembangkan kemampuan menyampaikan gagasan mencakup penjelasan gagasan, diagram, catatan dan pembicaraan lisan; 2) mengembangkan kemampuan pemecahan masalah; 3) mengembangkan aktivitas kreatif dengan pelibatan penemuan, intuisi dan imajinasi dengan mencoba-coba, membuat dugaan dan prediksi, rasa ingin tahu dan mengembangkan pemikiran divergen; 4) melatih bernalar dan cara berpikir pada penarikan kesimpulan, contohnya kegiatan eksperimen, eksplorasi, memperlihatkan perbedaan dan persamaan serta inkonsisten dan konsisten. Proses pembelajaran yang menggunakan alat peraga dapat memfasilitasi siswa untuk mengembangkan kemampuan menyampaikan gagasan dan penjelasannya, mengasah kemampuan dalam memecahkan permasalahan, medorong terlaksananya aktivitas kreatif melalui penemuan atau mencoba-coba sehingga timbul rasa ingin tahu, dan bernalar untuk menarikan kesimpulan.

Berdasarkan hasil observasi diperoleh informasi bahwa pembelajaran matematika di kelas VI SD Negeri Tamansari Kota Tasikmalaya masih memanfaatkan pola pembelajaran yang konvensional yakni penyampaian materi dari guru kepada siswa yang masih mendominasi. Pada sistem ini siswa sama sekali tidak terlibat dalam pembelajaran secara aktif yang mengakibatkan siswa tidak semangat dan jenuh. Pembelajaran konvensional yang dalam hal ini adalah metode ceramah merupakan proses pembelajaran yang mensetting seluruh tugas matematika diurutkan dengan hati-hati dan desain yang dimanfaatkan membuat akumulasi pengetahuan dengan segala perhitungan dan operasi hitung fakta dasar yang dihapalkan. Dilihat efisien tidaknya waktu, pembelajaran model ini sangat efisien sebab apa yang disampaikan guru langsung diterima dan siswa cenderung diam hanya saja tidak menyenangkan, siswa menjadi bosan dan juga jenuh. Monotonnya pembelajaran ini akibat tidak disertai strategi atau metode yang tepat, model dan rasa keingintahuan yang tinggi serta pembelajaran yang membosankan.

Menurut hasil wawancara dengan guru matematika kelas VI SD Negeri Tamansari Kota Tasikmalaya diprediksi bahwa pembelajaran konvensional yang selama ini dilakukan merupakan penyebab dari tidak sesuainya hasil belajar siswa dengan harapan. Kenyataan di lapangan 
menunjukkan bahwa masih banyak siswa yang belum mencapai nilai KKM yang berarti bahwa hasil belajar siswa tidak termasuk pada kategori baik. Hal ini merupakan suatu permasalahan yang penting untuk dicari solusinya agar hasil belajar siswa dapat meningkat.

Guna mengatasi hal ini, upaya yang dapat dilaksanakan yakni proses pembelajaran yang dirancang dengan pelibatan siswa secara aktif, salah satunya adalah dengan menggunakan alat peraga sebagai media pembelajaran. Alat peraga yang juga dikenal sebagai media menjadi alat untuk mengantarkan dan menyampaikan pesan dalam pembelajaran. Mengacu Djamarah dan Zain (2006) media ialah alat yang dapat membantu menyalurkan pesan agar tujuan pembelajaran dapat tercapai. Alat peraga merupakan media pembelajaran yang mampu menjadi pengantar pesan, menjadi pemicu kemauan, perasaaan dan fikiran siswa yang mana mampu memberikan dorongan peningkatan pemahaman materi sehingga dapat meningkatkan hasil belajar siswa.

Beberapa hasil penelitian menunjukkan bahwa pemanfaatan alat peraga pada pembelajaran matematika di sekolah dasar dapat meningkatkan hasil belajar siswa secara signifikan (Komalasari,2010; Putri, 2017; Hikmah, 2016). Berdasarkan latar belakang tersebut maka peneliti merumuskan tujuan penelitian tindakan ini adalah untuk mendeskripsikan peningkatan hasil belajar matematika siswa kelas VI SD Negeri Tamansari Kota Tasikmalaya pada materi bangun ruang melalui penggunaan alat peraga.

\section{METODE PENELITIAN}

Lokasi penyelengaraan penelitian perbaikan pembelajaran ini di kelas VI SD Negeri Tamansari, Kecamatan Kawalu, Kota Tasikmalaya pada tahun pelajaran 2017/2018. Mata pelajaran yang diteliti adalah Matematika. Pelaksanaan penelitian yakni bulan Februari 2018. Jumlah siswa kelas $\mathrm{VI}$ yang akan mendapat perlakuan khusus agar mengalami peningkatan hasil belajar adalah sebanyak 19 orang. Setiap siswa masing-masing memiliki sifat heterogen, artinya satu sama lain memiliki keunggulan dan kelemahan yang berbeda, terutama kemampuannya dalam mempelajari materi ajar yang akan mendapatkan tindakan dalam penelitian perbaikan pembelajaran ini.

Penelitian ini merupakan Penelitian Tindakan Kelas (PTK). Mengacu Wardhani (2007) PTK ialah penelitian yang dilaksanakan guru di kelas masing-masing dengan merefleksikan diri, dimana tujuannya guna perbaikan kinerja guru yang membuat peningkatan hasil belajar siswa. Pelaksanakan studi PTK menjadi usaha perbaikan praktek pendidikan secara sistematis dengan merefleksikan tindakan praktis yang dilakukan. PTK dilakukan berbentuk siklus yang mencakup sejumlah fase atau tahapan yakni perencanaan (planning), tindakan (action), pengamatan (observation), dan refleksi (reflection).

Model yang dimanfaatkan PTK ini yakni Model Kemmis dan Mc. Taggart karena model ini cocok dengan masalah yang diteliti. Desain ini memanfaatkan model yang disebut sistem spiral refleksi diri yang mulanya melalui rencana, tindakan, pengamatan atau observasi, refleksi, dan perencanaan kembali menjadi dasar guna ancang-ancang masalah yang dipecahkan (Arikunto, 2006). Desain model yang digunakan seperti dalam Gambar 1. 


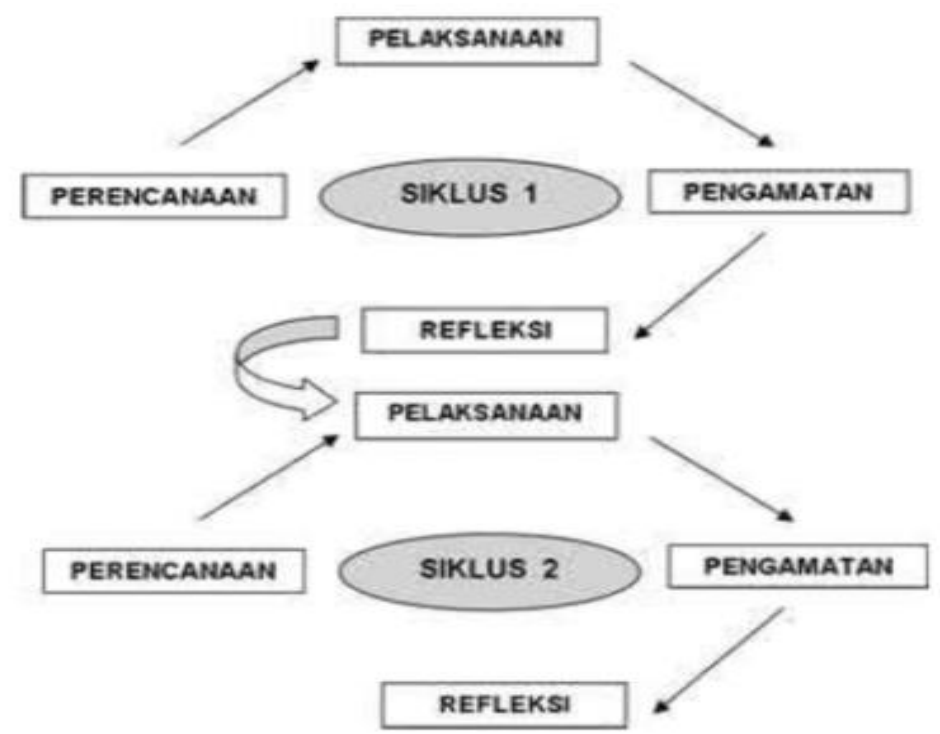

Gambar 1. Desain PTK Model Kemmis dan Mc. Taggart

a. Siklus I

1) Tahap Perencanaan

Dalam tahapan ini dilaksanakan penyusunan Rencana Pelaksanaan Pembelajaran (RPP) tentang mengenal beberapa bangun ruang balok dan kubus serta perhitungan volume dan luas bangun ruang tersebut, soal tes siklus I, serta lembar observasi keterlaksanaan pembelajaran matematika materi bangun ruang memanfaatkan bantuan alat peraga sederhana yang ada di lingkungan sekolah dan rumah.

2) Pelaksanaan Tindakan

Pelaksanaan kegiatan pembelajaran matematika memanfaatkan bantuan alat peraga sederhana yang ada di lingkungan sekolah dan rumah siswa misalnya menggunakan kemasan pasta gigi sebagai contoh bangun balok serta dadu sebagai contoh kubus serta benda-benda lainnya.

3) Pengamatan/Observasi

Pelaksanaan pengamatan peneliti oleh rekan sejawat (observer) guna mengobservasi aktivitas guru dan siswa selama proses belajar mengajar matematika yang memanfaatkan lembar observasi keterlaksanaan proses kegiatan belajar mengajar yang sudah disusun.

4) Refleksi

Peneliti melakukan pengumpulan dan analisis data yang didapat ketika pengamatan dan tindakan yang sudah dilakukan, agar bisa disimpulkan dan dimanfaatkan sebagai pedoman rencana siklus selanjutnya.

b. Siklus II

Dilakukan pengulangan tahap pada siklus I ke siklus II. Penyusunan perencanaan tindakan siklus II mengacu pada apa yang direfleksikan siklus I disertai sejumlah penyempurnaan yang dibutuhkan. Hasil penelitian dianalisis dan ditentukan apakah sudah memenuhi kriteria keberhasilan tindakan atau belum.

Teknik pengumpulan data yang dilakukan dalam penelitian ini meliputi:

1. Observasi

Instrumen yang digunakan berbentuk lembaran observasi siswa dan guru. Isi dari lembar observasi ini yakni indikator yang oleh observer harus dijawab mengacu observasi yang dihasilkan di lapangan, oleh karenanya akan didapatkan masukan dan informasi guna memperbaiki dan siklus selanjutnya dapat meningkat. 


\section{Tes}

Pelaksanaan tes yakni dua kali yaitu pada siklus I satu kali dan siklus II satu kali. Bentuk soal tes adalah pilihan ganda berjumlah 10 soal dengan memanfaatkan C1 (pengetahuan), C2 (pemahaman), dan C3 (penerapan). Pelaksanaan tes dilakukan di akhir pembelajaran pada masingmasing siklus. Tindakan dikatakan berhasil apabila mencapai kriteria yang ditetapkan yaitu jumlah siswa yang mencapai Kriteria Ketuntasan Minimum (KKM) sebanyak $75 \%$ dan rata-rata nilai matematika melebihi KKM 70.

\section{HASIL DAN PEMBAHASAN}

Perencanaan pembelajaran dalam pelaksanaan proses belajar mengajar dengan menggunakan alat peraga memperlihatkan siklus I yang meningkat ke siklus II. Mengacu analisis hasil penelitian secara keseluruhan nilai persentase merencanakan pembelajaran meningkat. Tindakan yang dihasilkan berwujud ativitas guru, hasil belajar siswa, dan aktivitas belajar siswa, dari tiap siklus pada setiap siklus dijabarkan sebagai berikut:

\section{a. Siklus I}

Mengacu data hasil tindakan dan observasi yang didapat pada siklus pertama maka dapat digambarkan :

1) Aktivitas belajar siswa

Pada siklus I situasi dan suasan belajar masih kurang kondusif karena siswa sedikit tidak terbiasa dengan adanya guru lain sebagai observer. Beberapa siswa terlihat kurang aktif dalam melakukan pengamatan menggunakan alat peraga.

2) Aktivitas guru dalam pembelajaran

Guru masih kurang maksimal dalam pemberian bimbingan pada siswa secara langsung dimana belum dan masih mendominasi ketika menggunakan media atau alat peraga. Kesimpulan yang diambilpun hanya dilaksanakan guru tanpa adanya keterlibatan siswa.

3) Hasil Prestasi Belajar Siswa

Pada akhir siklus I tingkat ketuntasan belajar siswa yang dicapai baru $25 \%$, belum melebihi ketetapan indikator keberhasilan yakni $75 \%$, oleh karenanya dibutuhkan tindakan siklus kedua. Pencapaian rata-rata kelas pun masih dibawah KKM yakni 58,5. Dengan demikian tindakan kelanjutan juga masih diperlukan. Data hasil belajar siswa selengkapnya pada siklus I disajikan pada Tabel 1.

\section{b. Siklus II}

Mengacu hasil yang direfleksikan siklus I dilaksanakan sejumlah upaya guna memperbaiki proses belajar megajar pada siklus II. Berdasarkan data hasil observasi dan tindakan yang didapat pada siklus kedua diperoleh gambaran sebagai berikut:

1) Aktivitas belajar siswa

Siswa berada pada kondisi pembelajaran yang kondusif dan tidak terlihat ketegangan sebab siswa mulai terbiasa dengan hadirnya observer ketika berlangsungnya proses belajar mengajar. Ketika mendengarkan tujuan pembelajaran siswa terlihat sudah memahami walaupun sejumlah anak tidak memberikan perhatian. Mayoritas siswa telah aktif melakukan demonstrasi, dan terlihat lebih antusias. Siswa terlihat tidak canggung dan sudah mulai terbiasa menggunakan media pembelajaran.

2) Aktivitas guru dalam pembelajaran

Pemberian motivasi dan apersepsi oleh guru yang menarik perhatian siswa. Guru terlihat secara langsung memberi bimbingan pada siswa yang belum memahaminya. Dalam penggunaan media dan demonstrasi guru tidak mendominasinya. Guru menyediakan alat peraga yang lebih banyak agar dapat digunakan dengan lebih leluasa.

3) Hasil Prestasi Belajar Siswa

Pada tes akhir siklus kedua tingkat pencapaian ketuntasan belajar siswa mencapai $100 \%$. Pencapaian rata-rata kelas sudah memenuhi KKM yakni 80 sehingga sudah memenuhi kriteria 
keberhasilan tindakan yang diharapkan sehingga tidak memerlukan siklus lanjutan. Data perbandingan hasil belajar siswa selengkapnya pada siklus I dan II seperti Tabel 1.

Tabel 1.

Rekapitulasi Hasil Belajar Siswa dalam pembelajaran Matematika tentang Bangun Ruang melalui Alat peraga

\begin{tabular}{cccc}
\hline \multirow{2}{*}{ No. } & & Siswa & \multicolumn{2}{c}{ Skor } \\
& & Siklus I & Siklus II \\
\hline 1 & S1 & 60 & 90 \\
2 & S2 & 60 & 90 \\
3 & S3 & 70 & 90 \\
4 & S4 & 60 & 90 \\
5 & S5 & 50 & 80 \\
6 & S6 & 50 & 70 \\
7 & S7 & 60 & 80 \\
8 & S8 & 70 & 70 \\
9 & S9 & 70 & 80 \\
10 & S10 & 50 & 70 \\
11 & S11 & 60 & 70 \\
12 & S12 & 50 & 80 \\
13 & S13 & 50 & 80 \\
14 & S14 & 50 & 80 \\
15 & S15 & 60 & 90 \\
16 & S16 & 50 & 80 \\
17 & S17 & 70 & 80 \\
18 & S18 & 50 & 70 \\
19 & S19 & 60 & 70 \\
& Jumlah & 1170 & 1600 \\
& Rata-rata & $\mathbf{5 8 , 5}$ & $\mathbf{8 0}$ \\
\hline
\end{tabular}

Berdasarkan Tabel 1 menunjukkan adanya peningkatan skor rata-rata siswa setelah dilakukan perbandingan dengan sebelum dilakukannya tindakan perbaikan. Hal ini bisa memperlihatkan kemampuan siswa yang optimal. Berdasarkan data observasi selama siklus I dan siklus II, membuktikan bahwa kemampuan siswa dalam pembelajaran matematika pada materi bangun ruang telah mengalami peningkatan. Peningkatan nilai rata-rata kelas pada selama tindakan perbaikan seperti bisa diketahui pada diagram Gambar 2.

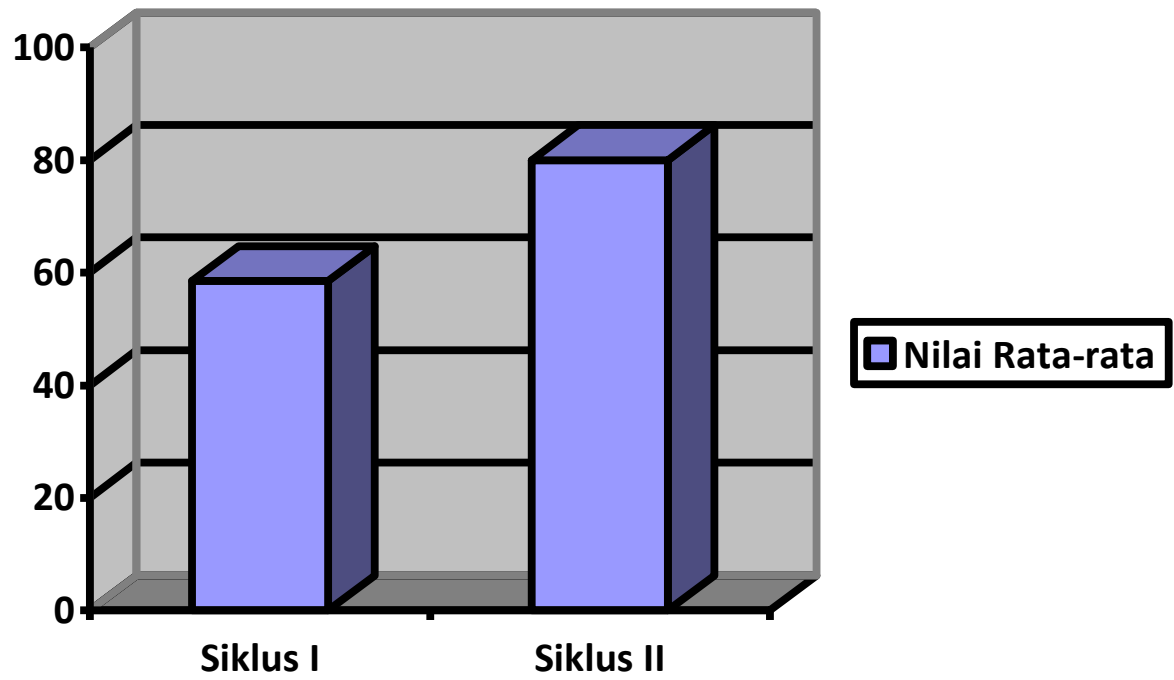

Gambar 2. Perbandingan nilai rata-rata siswa Siklus I dan Siklus II 
Peningkatan pemahaman siswa dalam pembelajaran Matematika pada materi bangun ruang melalui penggunaan alat peraga dikarenakan oleh timbulnya rasa senang dan nyaman dalam diri siswa sehingga membuat siswa merasa lebih percaya diri, timbul keberanian, dan lebih termotivasi untuk mengikuti proses pembelajaran. Hal ini menunjukkan bahwa hasil belajar matematika akan mengalami peningkatan jika siswa melakukan pembelajaran matematika dengan menggunakan alat peraga (Komalasari,2010; Putri, 2017; Hikmah, 2016).

Hasil penelitian ini sesuai dengan hasil penelitian Mariani (2009) dan Hikmah (2017) dimana hasil penelitiannya menyatakan bahwa pembelajaran matematika dengan memanfaatkan alat peraga dapat membawa peningkatan hasil belajar siswa. Pendekatan konstruktivistik dengan alat peraga berfous pada pengetahuan siswa yang dibentuk. Selama proses pembelajaran siswa dibiasakan melakukan konstruksi kognitif melalui kegiatan yang melibatkan alat peraga, bukan pengetahuan yang ditransfer dari pikiran guru ke siswa begitu saja. Siswa memerlukan benda konkret sebagai visualisasi untuk dapat memahami konsep materi yang dipelajari. Pada pembelajaran dengan pendekatan konstruktivistik yang dibantu alat peraga, siswa terbiasa membawa konsepsi awal mereka yang didapatkan selama melakukan interaksi dengan lingkungan dalam kegiatan pembelajaran. Hal ini mengakibatkan mudahnya siswa untuk lebih paham terhadap konsep yang diajarkan yang mana imbasnya pada hasil belajar siswa yang meningkat.

\section{KESIMPULAN}

Berdasarkan hasil analisis diperoleh data nilai rata-rata matematika mengalami peningkatan pada siklus I siswa dengan KKM yang terpenuhi adalah 5 orang siswa atau sebesar $25 \%$ sedangkan $75 \%$ lainnya belum tuntas sehingga penelitian berlanjut ke siklus II. Hasil belajar siswa pada siklus II meningkat dengan signifikan yaitu $100 \%$ siswa sudah mencapai ketuntasan. Rata-rata nilai siswa juga meningkatan pada siklus I yakni 58,5 sedangkan perolehan nilai rata-rata pada siklus II yakni 80. Hasil tersebut sudah memenuhi kriteria keberhasilan yang ditetapkan sehingga bisa diambil kesimpulan alat peraga yang digunakan pada pembelajaran materi bangun ruang membawa peningkatan hasil belajar matematika siswa kelas VI SD Negeri Tamansari Kota Tasikmalaya.

\section{REKOMENDASI}

Hasil penelitian yang dilaksanakan masih perlu dilaksanakan kelanjutanya. Bagi peneliti berikutnya hendaknya memanfaatkan ragam alat peraga yang digunakan pada kegiatan belajar mengajar matematika materi bangun ruang lebih banyak lagi jenisnya sehingga siswa lebih mudah dalam memahami konsep karena dipelajari dengan observasi benda-benda di lingkungan. Peneliti lain juga dapat mengembangkan penelitian pada materi dan mata pelajaran lainnya.

\section{UCAPAN TERIMAKASIH}

Ucapan terima kasih ditujukan kepada kepala sekolah yang telah mengizinkan penelitian ini, subyek penelitian ini yakni siswa-siswa kelas VI SD Negeri Tamansari Kecamatan Kawalu Kota Tasikmalaya serta para guru dan tenaga kependidikan yang telah mendukung pelaksanaan penelitian ini.

\section{DAFTAR PUSTAKA}

Arikunto, S. (2006). Penelitian Tindakan Kelas. Jakarta: Bumi Aksara.

Depdiknas. (2003). Pendekatan Kontekstual: Contextual Teaching and Learning (CTL). Jakarta : Ditjen Dikdasmen.

Djamarah, S. B., \& Zain, A. (2006). Strategi Belajar Mengajar (Edisi Revisi). Jakarta: Rineka Cipta. 
Hikmah, N. (2016). Peningkatan Hasil Belajar Matematika Tentang Penjumlahan dan Pengurangan Bilangan Bulat Melalui Alat Peraga Mistar Bilangan Pada Siswa Kelas IV SDN 005 Samarinda Ulu. Pendas Mahakam. Jurnal Pendidikan Dasar, Vol1 (1), p. 80-85.

Komalasari. (2010). Pembelajaran Kontekstual Konsep Aplikasi. Bandung: Refika Aditama.

Mariani. (2009). Pengaruh Pembelajaran Kontekstual dan Motivasi Berprestasi Terhadap Hasil Pembelajaran IPA pada Siswa Kelas V di SDN 1 dan 3 Renon Denpasar Selatan. Undiksha.

Putri, A. D. (2017). Peningkatkan Hasil Belajar Matematika Dengan Menggunakan Alat Peraga Jam Sudut Pada Peserta Didik Kelas IV SDN 2 Sunur Sumatera Selatan. Undergraduate thesis, IAIN Raden Intan Lampung.

Suwardi., Firmiana, M. E., \& Rohayati. (2014). Pengaruh Penggunaan Alat Peraga terhadap Hasil Pembelajaran Matematika pada Anak Usia Dini. Jurnal Al-Azhar Indonesia Seri Humaniora, Vol. 2 (4), p. 297-305.

Wardhani, I. (2007). Penelitian Tindakan Kelas. Jakarta:Universitas Terbuka. 